\title{
Estimation of the Calorific Value and Electrical Energy Potential of Waste Generated Biomass Within Abakaliki Meteropolis Ebonyi State, Nigeria
}

\author{
Igbo Micheal Elem ${ }^{1}$, Chikeleze Praise Chukwuemeka ${ }^{2}$, Augustine Ike Onyia ${ }^{2}$, \\ Igbo Nkechinyere Elem ${ }^{1}$, Eze Calister Ngozi $^{3}$, Chima Abraham Iheanyichukwu ${ }^{2, *}$ \\ ${ }^{1}$ Department of Science Laboratory Technology, Akanu Ibiam Federal Polytechnic, Unwana, Ebonyi State, Nigeria \\ ${ }^{2}$ Department of Industrial Physics, Enugu State University of Science and Technology, Enugu, Enugu State, Nigeria \\ ${ }^{3}$ Department of Physics, Federal University of Technology Minna, Minna, Niger State, Nigeria
}

Email address:

Abraham.chima@esut.edu.ng (C. A. Iheanyichukwu)

${ }^{*}$ Corresponding author

\section{To cite this article:}

Igbo Micheal Elem, Chikeleze Praise Chukwuemeka, Augustine Ike Onyia, Igbo Nkechinyere Elem, Eze Calister Ngozi, Chima Abraham Iheanyichukwu. Estimation of the Calorific Value and Electrical Energy Potential of Waste Generated Biomass Within Abakaliki Meteropolis Ebonyi State Nigeria. American Journal of Nano Research and Applications. Vol. 8, No. 3, 2020, pp. 42-49.

doi: 10.11648/j.nano.20200803.12

Received: August 20, 2020; Accepted: August 31, 2020; Published: September 14, 2020

\begin{abstract}
This study was conducted to determine the electrical energy potential of municipal solid waste (MSW) generated biomass within Abakaliki metropolis, Ebonyi State, Nigeria. The MSW samples were collected at two different points from each of the waste management zones, with each zone covering at least twelve (12) streets. It was then sorted into three major categories according to their constituents viz; metals, plastics and biomass. In this study, the biomass component of the MSW sample was is our focus. Thus, the biomass sample was sun dried and then ground into powdered form. It was thoroughly mixed, shredded, sieved and subsequently analysed at the Lorcin Technologies Port Harcourt, Nigeria. Currently, an average of 360 tons of MSW is generated within Abakaliki metropolis on daily bases. This translates to an electrical energy potential of approximately 320MW. The MSW-generated biomass analysis estimates the Gross Calorific Value (GCV) or Higher Heating Values (HHV) to be $11.644 \mathrm{MJ} / \mathrm{kg}$. This value which practically determines the electrical energy of the waste sample is highly suitable for many thermal conversion processe. This translate to the fact $0.925 \mathrm{~kg}$ of biomass will generate electrical power of $1 \mathrm{KWh}$. Hence, one unit of electricity $=10765 \mathrm{KJ} / \mathrm{Kg} / \mathrm{GVC}(\mathrm{KJ} / \mathrm{Kg})$.
\end{abstract}

Keywords: Municipal Solid Waste, Biomass Energy, Calorific Value

\section{Introduction}

In our day to day life experience, we are directly or indirectly involved in activities whose result is an end product that is not primed. This unprimed product is known as waste. A good example of this waste (unwanted materials) is disposed in an uncontrolled manner within Abakaliki metropolis. Hence, waste is an unavoidable by-product of human activities. Also wastes are material products for which the initial user has no further need in terms of his or her own purpose of production, transformation, or consumption and of which he or she wants to dispose [1].
Similarly, wastes can be regarded as unwanted or undesirable materials, or substance which are discarded after primary usage, or simply put as worthless and defective materials that are of no use. Examples are municipal solid waste (house hold trash, refuse), hazardous waste, waste water i.e sewage which contain bodily waste (urine and feces) and others. For the purpose of this work, the term Municipal Solid Waste (MSW) denotes household waste generated within a particular geographical location. They are also known as trash or garbage i.e refuse or rubbish consisting of common household items that are discarded by the public. Garbage also refers to food waste as sometimes collected separately. The main constituents of municipal solid waste are food waste, 
market waste, yard waste, plastic and metal containers, product packaging material and other miscellaneous solid waste from residential, commercial, institutional and industrial sources, including industrial waste, agricultural waste, medical waste, radioactive waste and sewage sludge [2].

Presently, most MSW generated within Abakaliki Metropolis are dumped into borough pits. Some are disposed along road sides thereby causing threat to health of the citizens. According to [3], an estimated 25 percent of the world's energy and materials are consumed in the developing world while twice as much waste is generated in the consumption process. Waste can be classified into biodegradable and non- biodegradable wastes which are recyclable or non-recyclable.

The waste management system has not attained acceptable standard, hence waste management is particularly a serious issue in Abakaliki, Ebonyi State. On this basis, this work sort to develop techniques to manage MSW with a view to reducing the health hazards associated with poor management of solid wastes. Waste management is particularly a serious issue in Nigeria and Ebonyi State in particular (Abakaliki metropolis as a specific example).

One of the ways to manage and utilize the energy potential of these solid wastes especially the municipal solid waste generated biomass is its conversion to energy in the form of heat and electricity [4]. Biomass is considered as one of the categories of the municipal solid waste (MSW) in this study. Thus, in this work, the prospects of MSW generated biomass within Abakaliki metropolis will be investigated by estimating the Calorific Value (CV) and the Energy Potentials (EPs) of some selected dump site by Waste to Energy conversion approach.

Biomass energy refers to energy from organic materials. It is the only renewable energy sources that can provide all form of energy as liquid, solid and gas, and other essential chemical products from its bio-refinery processes. It can be converted into liquid transportation fuel, in the form of bioethanol and biodiesel, as methan and hydrogen gas, and solid form as fuel wood, charcoal. Thus, biomass provides multiple essential energy services such as electricity, heating, cooking and transport fuel [5].

Biomass energy continues to be the major energy sources of about $40 \%$ of the global population living in developing countries despite its drawbacks [2].

Presently, biomass energy in developing country is used in inefficient stoves where its conversion efficiency is about $10 \%$. Using inefficient system require huge amount of biomass to provide the required cooking energy demands. In rural areas, biomass is perceived as a free commodity collected from their backyards or from common sources. Thus, biomass involves a lot of environmental, economic, social and health issues. Therefore, environment friendly and efficient production and consumption system needs to be established [6].

Energy from waste is about taking waste and turning it into a useable form of energy. This includes electricity, heat and transport fuels e.g diesel and can be done in a range of ways, with incineration being the most common techniques [7].

The energy produced can be in the form of heating or cooling, conversion of the waste into a fuel for further use e.g transport fuel or a combination of these forms. All the organic material produced by plant or any conversion process involving life is called Biomass. Biomass also known as bio fuel or bio energy is obtained from organic materials either directly from plants or indirect from industrial, commercial, domestic or agricultural products [8].

Waste to energy conversion usually involves the production of biomass and the subsequent use of the biomass to generate energy. Biomass could be defined as the various types of animal and plant materials which are convertible to energy. Incineration, which is the most common method, involves heating the biomass so as to release the biomass energy and thereafter using it to generate electricity [9]. Biomass is the energy released from the degradation or fermentation of such organic matter like poultry waste, rice, weeds, human and animal excreta, corn stalks etc [10].

For the purpose of this work, we shall use the term "Waste to energy" to describe a number of treatment processes and technologies used to generate a useable form of energy and which also reduces the volume of municipal solid waste.

\section{Materials}

The following materials/equipment were used to carry out the study:

\section{i. Calorimeter}

A calorimeter is equipment used to measure the heat capacity of a substance. There are several types of calorimeter. For the purpose of this research, a bomb calorimeter was used. A bomb calorimeter is a type of constant-volume calorimeter used in measuring the heat of combustion of a particular reaction.

\section{ii. Cellophane Bags}

Cellophane bags were used for packing the MSW samples collected for the study. This is thin, transparent sheet made of regenerated cellulose, cellophane bags used in packaging substances. It has low permeability to air, water, oil, gases and etc.

iii. Mortar \&Pestle

These were used for the purpose of mixing, shredding or grinding samples of the municipal solid waste into a powdered form of fine texture.

iv. Weighing Balance

This is an electronic device used in measuring or determining the masses of weights or substance placed on it.

For dry biomass conversion processes, the first five properties are of interest while for wet biomass conversion processes the first and last properties are of interest.

Examples of wastes include the following:

i. Biodegradable waste e.g food and kitchen waste, green waste paper. 
ii. Recyclable materials e.g paper, glass, bottle, jars, tin, cans, aluminum, metal, certain plastics, fabrics, cloths, tire, batteries etc.

iii. Inert waste i.e construction and demolition waste, dirt rock debris.

iv. Electrical and electronic waste (EEW) e.g electrical appliances, light bulb, washing machine.

v. Composite waste such as condemned clothing and toys.

vi. Hazardous waste which includes paints, bulb \& tires.

Method

\subsection{Sample Collection}

The waste samples were collected in conjunction with the waste management and evacuation officers from the Ebonyi State Environmental Protection Agency (EBSEPA) under the ministry of Environment. The municipal solid waste dump sites within the study area were divided into fourteen (14) zones with each zone covering at least twelve (12) streets and their environs.

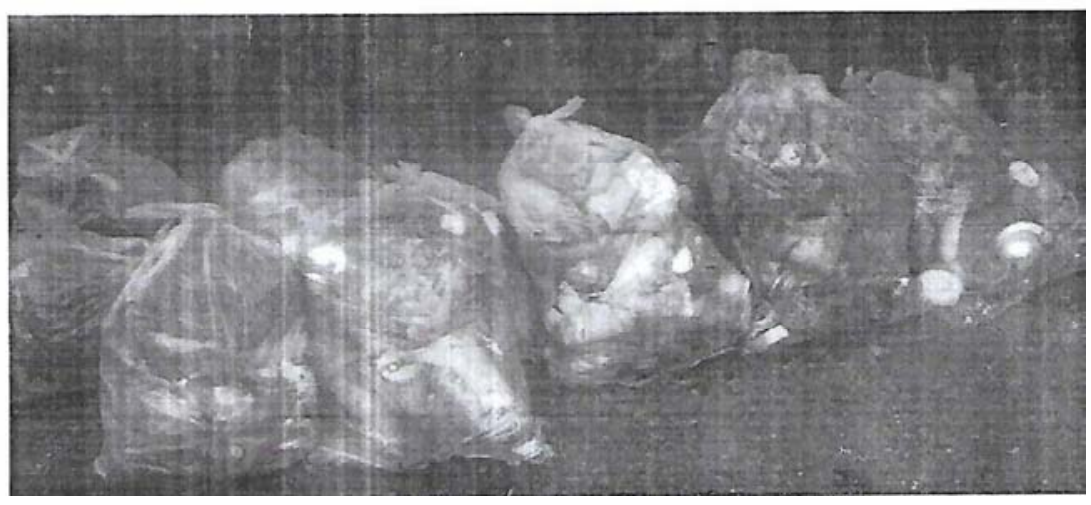

Figure 1. Collected Waste Samples.

Table 1. Waste Management Divisions (Zones) within Abakaliki Metropolis.

\begin{tabular}{|c|c|}
\hline Zone & Street compositions of the zones \\
\hline Zone 1 & $\begin{array}{l}\text { Udemezue Junction From Waterworks Keep Right To Ebia Bridge, Abofia Area, Igweorie St, Achi St, Laz Nwuzor St, Elias Odili St, Ben } \\
\text { Igwenyi St, Hill Top St, Egugwu Agbaja Area, Chinwe Elom St, Azugwu Rd and Environs, Waterworks Rd Keep right from Azugwu Junction } \\
\text { to Udemezue. }\end{array}$ \\
\hline Zone 2 & $\begin{array}{l}\text { Udensi street from roundabout keep right, Omega Rd, Uga St, Nna St, Olise Emeka St, Nsugbe St, Prison/FMC Rd, NITEL/Ministry of } \\
\text { Finance Rd, Leach St, Okpara, Awolowo, Liberty St, Ejiofor, Mberi }\end{array}$ \\
\hline Zone 3 & $\begin{array}{l}\text { Obiri Street from Afikpo Street Junction, Gunning Rd, Ojeowerri, Ziks Avenue, New Market Rd, Ogbe Hausa and Environs, Ikenga St, } \\
\text { Onicha St, Breakembuery, Ezekwesiri St, Hossana Hill, Hosanna park, Old park. }\end{array}$ \\
\hline Zone 4 & $\begin{array}{l}\text { ende St, Gilbert St, Igweogbofia St, Akpofe St, Nwojiji St, Aberiba, Muoreke, Chinedu Oga Street, Unity FM Rd From Ebebe Junction Keep } \\
\text { eft to St. Patrick Rd, St. Patrick Rd keep left, Kpiri-kpirikpiri market and environs, Ogbodudu St. }\end{array}$ \\
\hline Zone 5 & $\begin{array}{l}\text { St. Patrick Rd from old Enugu Rd keeping left, Nwiboko Enigwe Rd, Amike aba town hall Rd, Osborn Lapalm Rd, Stephen Mgbabor St, } \\
\text { Oreke onuoha Rd, NEPA power line Rd and environs, Mile } 50 \text { layout right, Ugwu Achara right, Mile } 4 \text { right, Nwambara junction right, } \\
\text { Enyibuchiri Rd, Ishieke right. }\end{array}$ \\
\hline Zone 6 & $\begin{array}{l}\text { Onwe Rd from Udensi roundabout keep right, EBSEC Rd, Ezza Rd, Adig Hotel St, Alo St, Item St, Nnorom St, Mbukobe and Environs, } \\
\text { Ukwu-akpu and Environs, From Spara-in-deo junction to umunze junction keeping right, Echieagu Rd, Pontus Ibeogu St. }\end{array}$ \\
\hline Zone 7 & $\begin{array}{l}\text { Old Enugu Rd, Mission Rd, Adol Awam avenue, Origbo St, Chukwuma Nwazunku, Amaeze Nwofo St, Ishieke campus (EBSU) left, Ishieke } \\
\text { market left, Ukwuachi left, NTA area, Liberation Estate, Water reservoir and environs }\end{array}$ \\
\hline Zone 8 & $\begin{array}{l}\text { Ekulumiri St, Ukpo St, Nibo St, Nise St, Afikpo Rd to spera in deo junction, Mbanefo St, Nnewi St, Ajali St, Nwankwo St, Igbokwe St, } \\
\text { Anakwe St, Mbadugha St. }\end{array}$ \\
\hline Zone 9 & $\begin{array}{l}\text { Isuoffia St, Onogoro St, Nssuka St, Nnofia, Mechanic site Rd, Onuebonyi junction, onuebonyi junction to International Market, Nnatu, } \\
\text { Mechanic site, International Market, Ogoja Rd from Chukwu St to Onuebonyi junction, Nwokpo. }\end{array}$ \\
\hline Zone 10 & $\begin{array}{l}\text { From Nkaliki Rd right to Nkaliki Primary School, hatchery Rd, Odumukwe St, Agwuncha St, Afoezunna St, Fide Mbam Farm, Democracy } \\
\text { Estate, CHS Presco Campus, Chiboy Street, Ajanwachukwu St, Agbabuzo St, Democracy Estate primary school Rd. }\end{array}$ \\
\hline
\end{tabular}

Similarly, data on daily waste generation within Abakaliki metropolis is shown in table 2 .

Table 2. Daily Waste Generation within Abakaliki Metropolis as at July, 2019.

\begin{tabular}{lll}
\hline S/N & Zone & Quantity of waste (Tons) \\
\hline 1. & Zone 1 & 42 \\
2. & Zone 2 & 32 \\
3. & Zone 3 & 41 \\
4. & Zone 4 & 42 \\
5. & Zone 5 & 33 \\
6. & Zone 6 & 40 \\
7. & Zone 7 & 34 \\
8. & Zone 8 & 40 \\
\hline
\end{tabular}




\begin{tabular}{|c|c|c|}
\hline $\mathbf{S} / \mathbf{N}$ & Zone & Quantity of waste (Tons) \\
\hline 9. & Zone 9 & 32 \\
\hline 10. & Zone 10 & 20 \\
\hline & Total & 360 \\
\hline
\end{tabular}

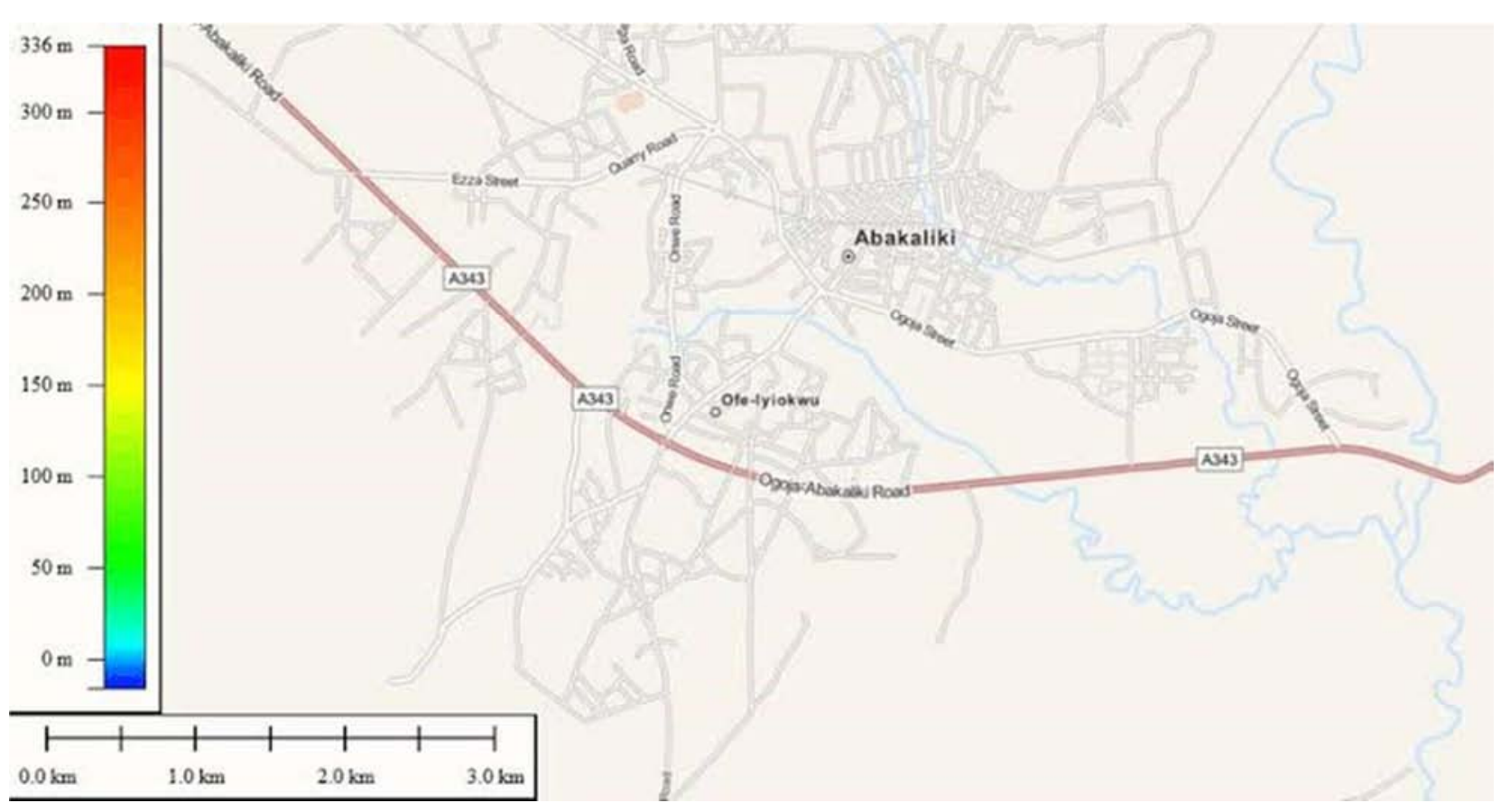

Figure 2. Waste management zones under reviews spread across Abakaliki metropolis.

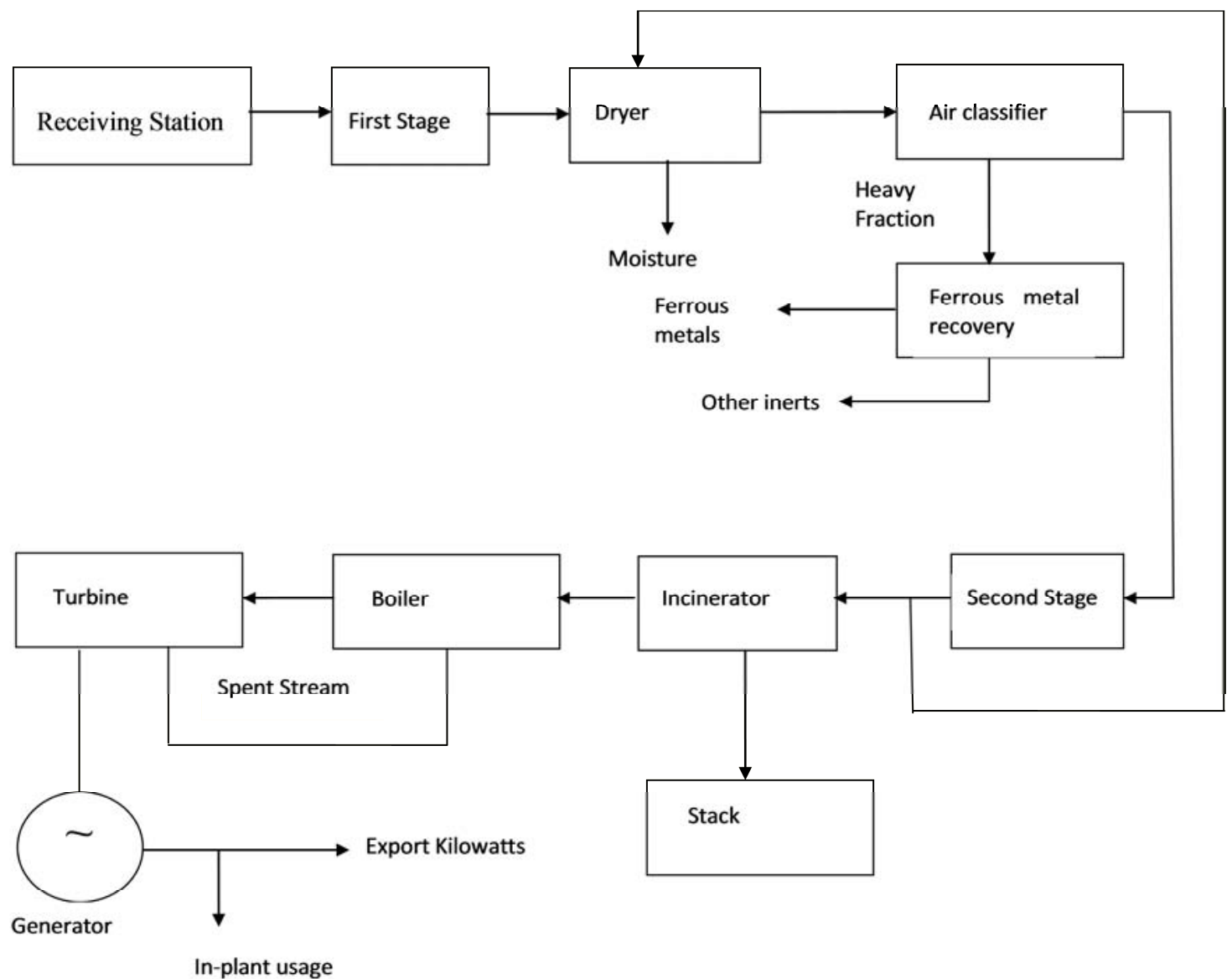

Figure 3. Flow chart for recovery of energy from solid waste. 


\subsection{Experimental Procedure}

Samples of the biomass sorted out from the MSW were sun dried and then ground into a rough powered form with the use of mortar and pestle. Then the five samples of the ground biomass were used to determine the moisture content, ash content and calorific value. Also, samples of the processed biomass from the MSW were used to determine the gross calorific value (GCV) by the method of calorimetry. Hence, the average GCV obtained for the biomass was used to estimate the electrical energy potential.

The waste samples were collected from two (2) different points at the MSW dump site in each zone. Then each of the samples was put inside a cellophane bag of a known mass. The mass of the samples was weighed and then, the mass of the sample obtained by deducting the mass of the cellophane bag containing the MSW samples previously weighed with an electronic weighing balance was recorded as $\mathrm{M}_{\mathrm{T}}$. Then each of the bags were opened and the contents sorted according to their categories; viz: metals, plastics and biomass. Each class was weighed separately and their individual masses recorded as; $\mathrm{M}_{\mathrm{M}}$, $\mathrm{M}_{\mathrm{P}}$ and $\mathrm{M}_{\mathrm{B}}$. Result obtained is as shown in table 3.

Where $\mathrm{M}_{\mathrm{T}}=$ Total mass of waste sample

$\mathrm{M}_{\mathrm{M}}=$ Mass of metal

$\mathrm{M}_{\mathrm{P}}=$ Mass of plastics

$\mathrm{M}_{\mathrm{B}}=$ Mass of biomass

$$
\text { But } \mathrm{M}_{\mathrm{B}}=\left[\mathrm{M}_{\mathrm{T}}-\left(\mathrm{M}_{\mathrm{M}}+\mathrm{M}_{\mathrm{P}}\right)\right] \text {. }
$$

\subsection{Wastes to Energy Conversion Mechanism}

The energy from wastes can be directly derived by converting municipal solid waste generated biomass into electricity as shown in figure 3 (waste to energy recovery flow chart).

First, the solid waste is collected from all the collection points. It is then transported to the receiving station. After this, the solid waste is fed to the shredder where it is cut down into small pieces so that it can be managed easily by at subsequent stages. Now the shred solid waste is passed through dryers to remove extra moisture. Then air is blown on the solid waste which separate light materials from heavy materials. The heavy materials (plastics and metals) are then sent for recycle as these materials cannot be burned in incinerators. The light solid waste is again passed through the second stage (shredder) to cut it into smaller pieces. Then the small solid waste is burned in incinerators which reduce the solid waste into ash and produce heat energy and gases. The gases are then passed through air filters which are subsequently released into the atmosphere through stacks. Heat energy is used to boil water in boilers to produce steam which in turn runs turbine that is coupled with generators. As the turbine runs, it causes the generator to rotate and produce electricity. This electricity can be exported to the grid and some of it used for plant itself.

\section{Results}

\subsection{Composite Analysis of the Sampled Msw}

Table 3. Composition of Sampled MSW.

\begin{tabular}{lllll}
\hline $\mathbf{S} / \mathbf{N}$ & $\mathbf{M}_{\mathbf{T}}(\mathbf{K g})$ & $\mathbf{M}_{\mathbf{M}}(\mathbf{K g})$ & $\mathbf{M}_{\mathbf{P}}(\mathbf{k g})$ & $\mathbf{M}_{\mathbf{B}}(\mathbf{K g})$ \\
\hline 1. & 1.800 & 0.100 & 0.100 & 1.600 \\
2. & 1.920 & 0.130 & 0.120 & 1.670 \\
3. & 1.900 & 0.450 & 0.200 & 1.250 \\
4. & 2.750 & 0.250 & 0.170 & 2.330 \\
5. & 2.600 & 0.300 & 0.250 & 0.050 \\
6. & 1.150 & 0.100 & 0.250 & 1.500 \\
7. & 1.700 & 0.050 & 0.150 & 1.800 \\
8. & 2.000 & 0.100 & 0.100 & 2.520 \\
9. & 2.950 & 0.200 & 0.230 & 1.690 \\
10. & 2.150 & 0.360 & 0.100 & 17.210 \\
TOTAL & 20.920 & 2.040 & 1.670 & \\
\hline
\end{tabular}

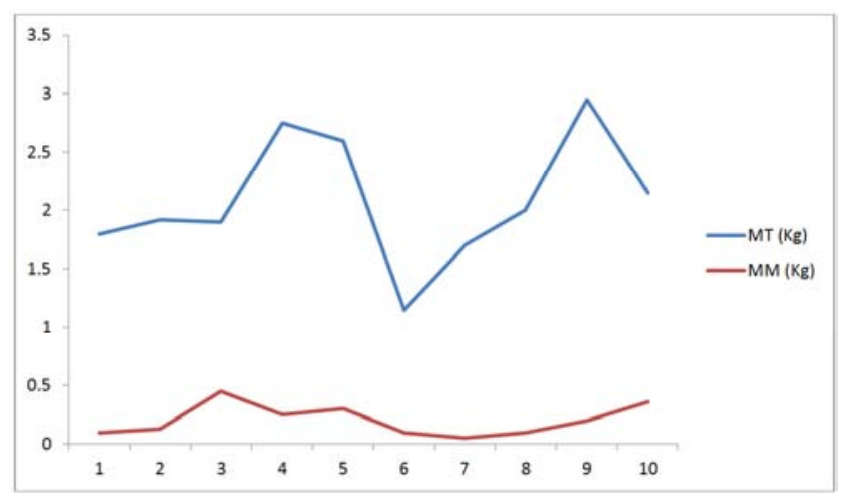

Figure 5. Showing sample of total mass of sample and mass of metal.

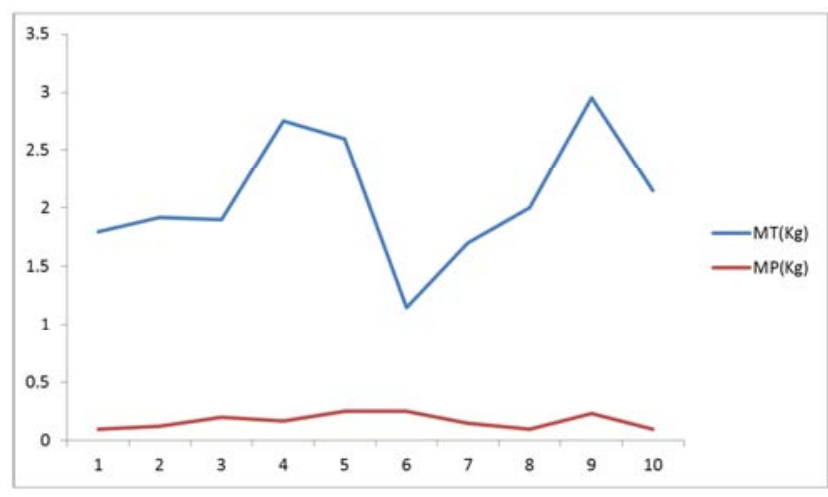

Figure 6. Showing sample of total mass of sample and mass of plastics. 


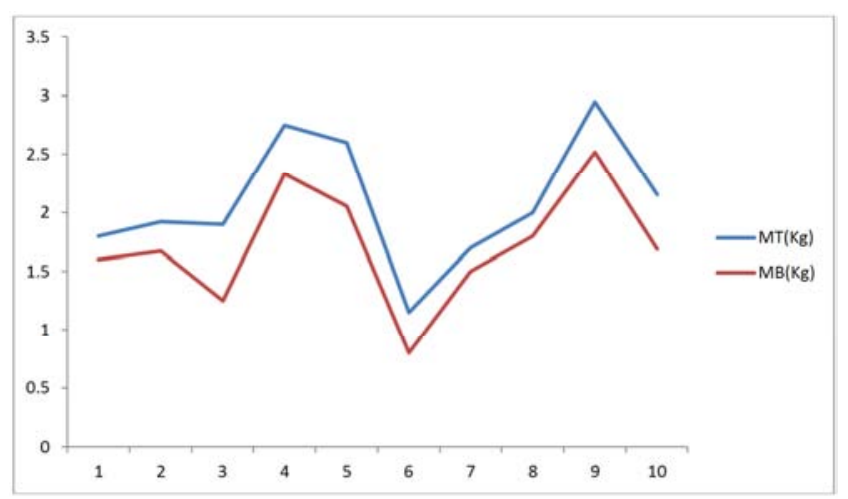

Figure 7. Showing sample of total mass of sample and mass of biomass.

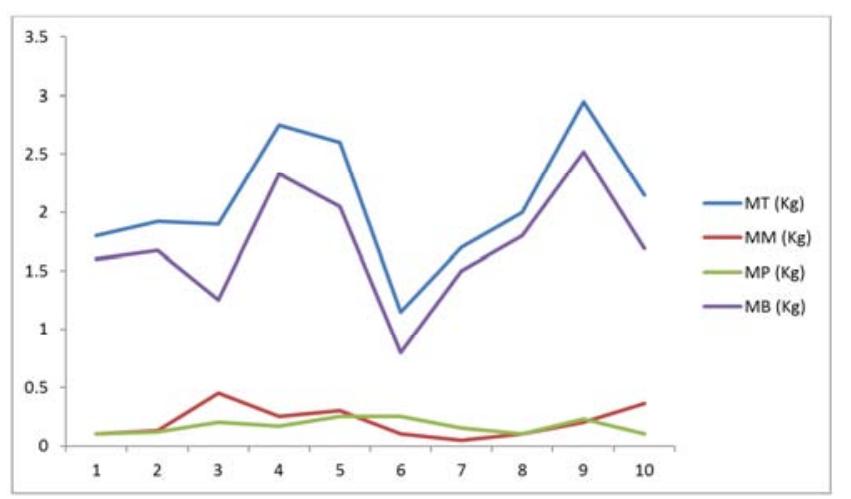

Figure 8. Showing sample of individual masses recorded as; $M_{T} M_{M}, M_{P}$ and $M_{B}$.

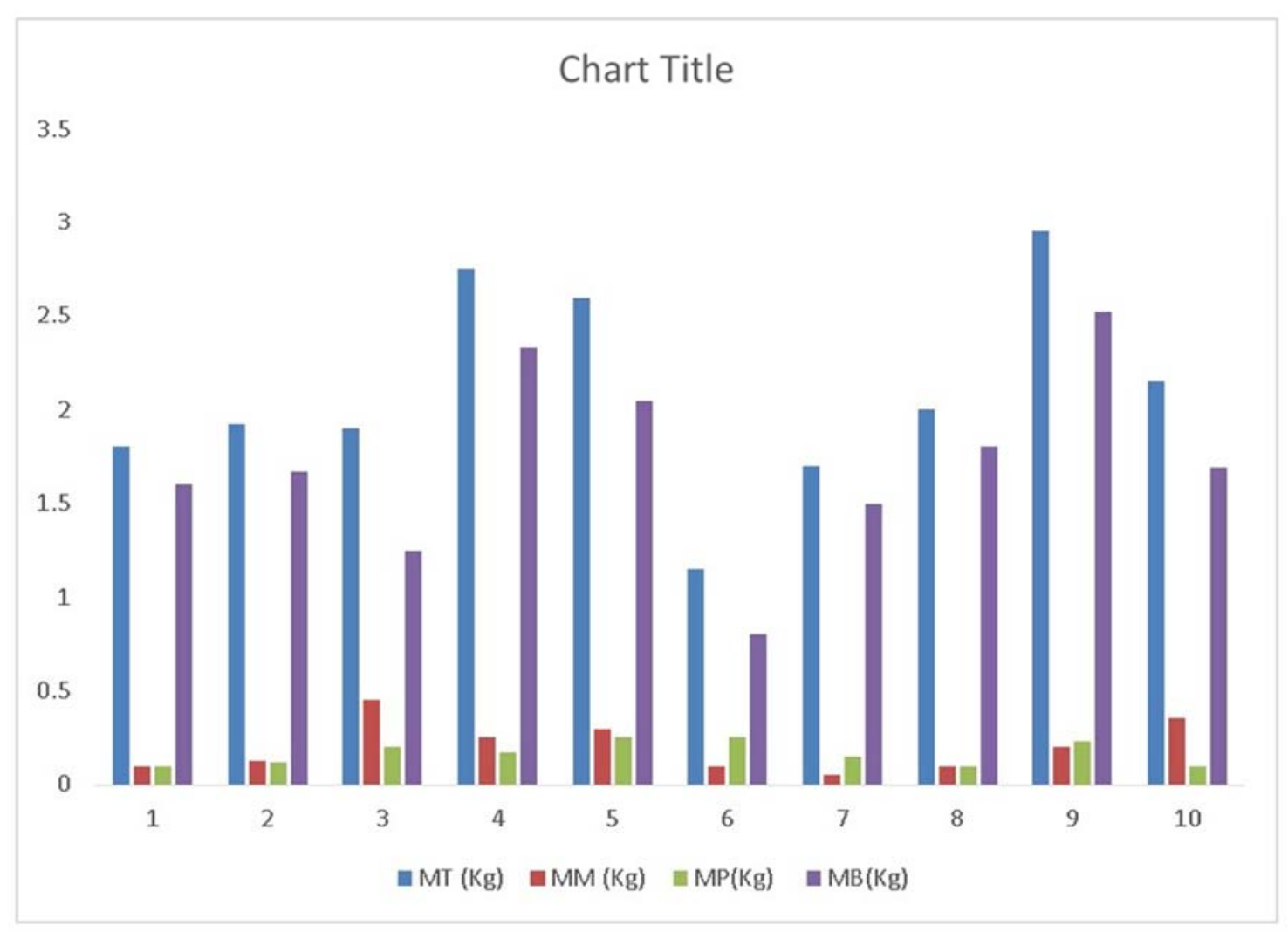

Figure 4. Bar chart showing the composition of the municipal solid waste sample (MSW).

Table 4. Results of Analyzed MSW Generated-Biomass.

\begin{tabular}{llll}
\hline Samples & $\begin{array}{l}\text { Moisture of received } \\
\text { MSW (wt, \%) }\end{array}$ & $\begin{array}{l}\text { Ash (wt. \%) } \\
\text { dry basis }\end{array}$ & $\begin{array}{l}\text { HHV } \\
\text { (MJ/Kg) }\end{array}$ \\
\hline 1 & 39.78 & 12.56 & 10.98 \\
2 & 45.67 & 10.28 & 12.16 \\
3 & 40.52 & 9.86 & 11.84 \\
4 & 42.55 & 13.81 & 11.56 \\
5 & 47,280 & 11.98 & 11.68 \\
Average value & 43,160 & 11.698 & 11.644 \\
\hline
\end{tabular}

\subsection{Biomass Contents of the Msw Sample}

The percentage of biomass present in municipal solid waste generated within Abakaliki was calculated using the figures obtained from the waste sampling results.

Total mass of the $\mathrm{M}_{\mathrm{b}}(\mathrm{kg})=17.210$
Total mass $0 \mathrm{f} \mathrm{M}_{\mathrm{T}}(\mathrm{kg})=20.920$ as shown in table 3

$$
\text { Percentage biomass }=\frac{17.210}{20.920} \times 100 \%=82.266 \%=82 \%
$$

\subsection{Gross Calorific Value (GCV) of the Msw Sample}

Samples of the processed biomass from the municipal solid waste were used to determine the Gross calorific value (GCV) by the method of Calorimetry, and the results are as shown in table 4.

\subsection{Electrical Energy Potential of the Msw Sample}

The electrical energy potential of the biomass from Municipal Solid Waste Generated at Abakaliki was calculated using the simple "combined power plant efficiency method", as put forward by [11]. The basic function of the power plant 
is to convert the energy in the biomass to electricity. Therefore, in order to determine the electrical energy yield from a given quantity of the biomass, the first thing that needs to be known is how much energy contained in the biomass.

\subsection{Biomass-Energy Content of the Msw Sample}

Energy content of biomass is given in KiloJoules $(\mathrm{kJ})$ per Kilogram $(\mathrm{kg})$ i.e. $\mathrm{KJ} / \mathrm{Kg}$ of biomass as the Gross Calorific Value (GCV) or the Higher Heating Value (HHV) of coal. This value usually varies depending on the quality of the biomass. For the purpose of this work, a Gross Calorific Value (GCV) of $11,644 \mathrm{KJ} / \mathrm{Kg}$ as determined from the analysis used.

\subsection{Efficiency of the Power Plant}

The efficiency of a biomass-based power plant denotes the degree to which the plant converts a unit mass of biomass to electrical energy. Energy conversion in biomass-based power plants takes place in two stages. The first part of the plant efficiency is the combustion efficiency of the boiler denoted as $E_{B}$. For this work, we assumed a value for $E_{B}=88 \%$ on a GCV basis which is within the normal range for a welloptimized power plant.

The second part of the plant efficiency is the steam cycle efficiency denoted as $E_{S}$. Modem Rankine cycle, adopted in biomass-based power plants, have efficiencies that vary from $32 \%$ to $42 \%$. This depends mainly on the steam parameters. Higher steam pressure and temperatures in the range of $600^{\circ} \mathrm{C}$ and 230 bars have efficiencies around $42 \%$. For the purpose of this work a value of $\mathrm{E}_{\mathrm{S}}=38 \%$ was assumed.

Therefore, the overall conversion efficiency of the power plant which is denoted as

Where $\mathrm{E}_{\mathrm{P}}=\mathrm{E}_{\mathrm{B}} \times \mathrm{E}_{\mathrm{S}}=(38 \% \times 88 \%)=33.44 \%$.

\subsection{Heat Production Rate of the Plant}

Heat rate is the heat input required to produce one unit of electricity i.e. one kilowatt hour $(1 \mathrm{kWh})$, where $1 \mathrm{KWh}=1000$ x $60 \times 60 \mathrm{~J}=3,600,000 \mathrm{~J}=3600 \mathrm{KJ}$.

To produce one unit of electricity we require $3600 \mathrm{KJ}$ i.e. assuming a $100 \%$ energy conversion efficiency.

After considering the conversion efficiency in a power plant we require a heat input of $(3600 \pm 33.44 \%)=10765$ $\mathrm{kJ} / \mathrm{kWh}$ to produce one unit of electricity.

\subsection{Biomass Consumption Rate of the Plant}

Given that the biomass has a GCV of $11,644 \mathrm{KJ} / \mathrm{kg}$, $1 \mathrm{kWh}=10765 / 11644=\mathrm{ft} 925 \mathrm{~kg}$ of biomass.

Given that the waste volume generated at Abakaliki=360 tons/day, since $82.266 \%$ of the waste is composed of biomass,

$$
\begin{aligned}
& \text { Therefore the quantity of biomass }=\frac{82}{100} \times 360 \\
& =296.158 \text { ton }
\end{aligned}
$$

But $1 \mathrm{KWh}=0.925 \mathrm{Kg}$ of biomass,

$$
\text { Therefore, } 296.158 \text { tons of biomass }=\frac{296.158}{0.925} \times 1000
$$$$
=116,862.2 \mathrm{MW} / \mathrm{yr}
$$

$$
=320170 \mathrm{KW} \text { daily. }
$$$$
=320 \mathrm{MW}
$$

\section{Discussions}

The Muncipal Solid Waste (MSW) samples considered in this work were sourced within Abakaliki Metropolis in collaboration with Ebonyi State Environmental Protection Agency (EBSEPA).

Available data in table 2 shows that 360 tons of wastes are generated on daily basis within Abakaliki metropolis.

Also, results of the physical composition of the MSW as presented in table 3 shows that the mass of biomass $\left(M_{B}\right)$ has the highest average value of $17.21 \mathrm{~kg}(82.2 \%)$ followed by mass of metal $\left(\mathrm{M}_{\mathrm{M}}\right)$ with average value of $2.04 \mathrm{~kg}(9.75 \%)$ while the mass of plastic (Mp) has the lowest average value of $1.67 \mathrm{~kg}(7.98 \%)$. This lays bare our interest on the enormous but untapped biomass source from MSW sample.

Similarly, results from table 3 show clearly the heterogeneous composition of the analyzed MSW sample.

Thus, each of the individual sub-samples of MSW $\left(\mathrm{M}_{\mathrm{B}}\right.$, $\left.M_{P} \& M_{M}\right)$ were related to the total mass $\left(M_{T}\right)$ sample as shown in figures; 5, 6 and 7.

However, some typical properties of interest in the MSWgenerated biomass were identified, analyzed and their results recorded as shown in table 4.

Thus, the average calorific value or higher heating value (HHV) in which the electrical energy generation capacity is dependent upon was estimated to be $11.644 \mathrm{MJ} / \mathrm{Kg}$. This value is quite high and therefore suitable for thermal conversion processes.

Moreso, from the calculated biomass consumption rate (BCR), it is evident that the volume of waste that would be generated annually within Abakaliki metropolis can effectively power a $300 \mathrm{MW}$ biomass-fired power plant to supply interrupted electricity in Abakaliki and its environs.

\section{Conclusion}

In this work, the Municipal Solid Waste (MSW) composition and their effects were studied. The results show that the MSW discharged within Abakaliki and its environs has higher percentage of biomass composition compared to plastic and metals.

Similarly, the municipal solid waste-generated biomass analysis estimates the Gross Calorific Value (GCV) or Higher Heating Values (HHV) to be $11.644 \mathrm{MJ} / \mathrm{kg}$. This value which practically determines the electrical energy of the waste sample was high. This translate to the fact $0.925 \mathrm{~kg}$ of biomass will generate electrical power of $1 \mathrm{KWh}$. Hence, one unit of electricity $=10765 \mathrm{KJ} / \mathrm{Kg} / \mathrm{GVC}(\mathrm{KJ} / \mathrm{Kg})$. This result was based on the estimate of about 360tons/day volume of waste generated within Abakaliki metropolis.

This recovery option of generating electricity from MSWbiomass is important as it offers alternative towards evaluating equipment needs, systems management and plans 
especially with respect to the implementation of disposal resources in this era of global warming. Energy from this source is environmentally, friendly, readily available and can turn our worthless materials into wealth.

\section{References}

[1] United Nations Statistics division. (1997). Glossary of Environmental Statistics. Revtrieved on July 12, 2019 from http/:www.un.org/statdiv.

[2] Obemberger, I and Thick, G. (2004). Physical Characterization and Characterisation and Chemical Composition of Densified Biomass Fuels with Regards to Combustion Behaviour. Journal of Biomass and Bioenergy, 27 (6), PP. 653-669.

[3] Rinkesh, C. L. (2009). Processing Division of Phsolysis. Science of Waste management and Climate in Nigeria 18 (2). PP. 1-19.

[4] Nickolas, J. T. (2003). An Overviews of the Global Waste to Energy Industry. Waste Management World. Retrieved on June 10, 2019.
[5] Farmer, H. and Hjerp, P. (2001). Municipal Solid Waste Incineration: Health Effects, Regulation and Public Communication Institute for European Environemntal Policy, London.

[6] Uzunn, B. B. Pyrolysis (2016): A sustainable way from waste to energy. from http/www.anadolu.edu. tr.

[7] Department for Environment, Food and Rural Affairs (2014). Energy from Waste: A guide to the debate. Retrieved on May 20, 2019. From http//www.gov.uk/defra.

[8] Klass, D. (2004). Biomass for Renewable Energy and Fuels. Encyclopedia of Energy, Elsevier Inc. Oxford.

[9] Mgbenu, E. N. Inyang, A. E. Agu, M. N, Osuwa, J. C.II, Ebong, I. D. U (1995). Modern Physics, Spectrum Books, Lagos.

[10] Anyakoha, M. W. (2011). New School Physics for Secondary School ( $4^{\text {th }}$ edition $)$, African Publishers, Lagos.

[11] Omari, A. M, Kichonge, B. N\, John, G. R, Njau, K. N, Mtui, PL (2014). Potential of Municipal Solid Waste as Renewable Energy Source: A case study of Arusha, Tanzania. International Journal of Renewable Energy Technology Measure 3 (6), PP. 1-9. 